\title{
NYOMÓKAMRÁVAL KOMBINÁLT CSÚSZÓVEZETÉK VIZSGÁLATA
}

\author{
Tóth Sándor Gergő \\ tanársegéd, Miskolci Egyetem, Szerszámgépészeti és Mechatronikai Intézet, \\ Szerszámgépek Intézeti Tanszéke \\ 3515 Miskolc, Miskolc-Egyetemváros, e-mail:sszgttosg@uni-miskolc.hu
}

\author{
Takács György \\ egyetemi docens, Miskolci Egyetem, Szerszámgépészeti és Mechatronikai Intézet, \\ Szerszámgépek Intézeti Tanszéke \\ 3515 Miskolc, Miskolc-Egyetemváros, e-mail:takacs.gyorgy@uni-miskolc.hu
}

\begin{abstract}
Absztrakt
Habár a nagy pontosságú szerszámgépekben hidrosztatikus vezetékek beépitése célszerü, a vezetékek legyártáshoz kivánt nagy gyártási pontosság, illetve a bonyolult hidraulikus rendszer kiépitése miatt egyre kevesebb vállalat foglalkozik ilyen vezetéktipus forgalmazásával. Egy tanszéki projekt keretében tervezendö portáljelü marógép pontosságának növelése érdekében speciális vezetékkonstrukciók kerültek megvizsgálásra, amelynek eredményeként egy hidraulikus nyomókamrákkal tehermentesitett csúszóvezeték konstrukció került megtervezésre. A tehermentesités nagyságának ellenörzéséhez egy méröpad került felállitásra. Az elvégzett elsödleges mérések alapján a konstrukcióval a tehermentesités megfelelö csúszófelület biztositásával megvalósul.
\end{abstract}

Kulcsszavak: hidraulika, csúszóvezeték, szerszámgép, nyomókamra, tehermentesités

\begin{abstract}
Although the apply of hydrostatic guideways in high precision machine tools is desirable, fewer companies are involved in marketing this type of guideway due to the high precision manufacturing required to produce the hydrostatic guideways and the complexity of the hydraulic system. In order to improve the accuracy of a portal-type milling machine to be designed as part of a departmental project, special guideway designs have been investigated, resulting in a slideway structure relieved with hydraulic pressure chambers. A measuring bench was set up to check the amount of relief. Based on the primary measurements performed, the structure relieves the load by providing a suitable sliding surface.
\end{abstract}

Keywords: hydraulic, slideways, machine tool, pressure chamber, load relief

\section{Bevezetés}

A konzorciumi partner többször adott javaslatot olyan jellegü függőleges vezeték konstrukcióra, ahol a súrlódó vezeték hidraulikus nyomókamrával van kiegészítve. Az egyes változatok esetében a hidraulikus nyomókamra kialakítása, elhelyezési módja és feladata eltérő. Közös jellemzője a megoldásoknak, hogy a keletkező résolaj a vezetékkonstrukción belül kerül összegyüjtésre és elvezetésre. A konzorciumi partner feltételezése szerint múködés közben a nyomókamrákat határoló tömítő felületeknél a 
gerenda és a nyomókamra megvezető gyürü vezető felülete közt kialakuló keskeny résen folyadékáram jön létre, a résáram önszabályzó módon állandó résméretet biztosít. Mivel a gerenda egy folyadék filmen mozdul el, ezért minimális előtoló erő lesz. A résáramot külső gyürü összegyüjti és elvezeti egy gyüjtővezetéken keresztül a tartályba. A kamrák alacsony, állandó értékủ néhány bar-os nagyságrendủ nyomását egy hidro-pneumatikus egység biztosítaná.

Három különböző, hidraulikával kombinált csúszóvezeték konstrukció található meg a szakirodalomban: hidrodinamikus csúszóvezetékek, nagymerevségü hidrosztatikus vezetékek, illetve részlegesen tehermentesített csúszóvezetékek [1], utóbbi konstrukció hasonlít a konzorciumi partner által javasolt vezeték tervhez.

\subsection{Részlegesen tehermentesített csúszóvezetékek}

A hidrosztatikus vezetékek, bár súrlódási ellenállása kicsi, alkalmazásuk különösen az előtolás irányban nehézségekbe ütközik. Annak érdekében, hogy a merevség és a csillapítási képesség egyaránt javuljon, egy olyan új konstrukció alkalmazható, amely lehetővé teszi a megfelelő nagyságú érintkezést a csúszófelületek között, megtartva a hidrosztatikus vezetékekre jellemzö érintkezés-mentes müködtetés néhány előnyét.

A részlegesen tehermentesített csúszóvezeték olyan konstrukció, amelyben a nyomás alatt álló kenőközeg, mint például a levegő a csúszófelületek közé kerül, hogy csökkentsük a csúszófelületre háruló terhelést, és ezáltal egy nehéz test simán mozogjon minimális súrlódási veszteséggel. A "részlegesen tehermentesített vezeték" elnevezés a vegyes kenés jellemzőjéből származik, ahol a csúszófelület egy része érintkezésmentesen csúszik, míg a többi felület érintkezik egymással. Abban az esetben, ha a sürített levegőt a holtsúly csökkentésére használják, a gépet nem kell kenőanyag-keringtető rendszerrel felszerelni. Ez az oka annak, hogy ezt a pneumatikus rendszert általában a holtsúly csökkentésére használják.

A levegő szivárgásának megakadályozása és a sürített levegő nyomáscsökkenésének elkerülése érdekében szükséges az alkatrészek nagy pontosságú vezérlése. Továbbá, a levegővel tehermentesített csúszóvezetékek felületei hajlamosak az úszásra, amikor a felületnyomás enyhül. Emiatt a fejlesztések korai fázisában az olajjal tehermentesített csúszóvezetékek kerültek elötérbe [2].

1. táblázat. Levegővel és olajjal tehermentesitett csúszóvezetékek összehasonlitása [1].

\begin{tabular}{|l|c|c|}
\hline $\begin{array}{c}\text { Megjegyzés: } \\
\text { O/X - adott konstrukció ren- } \\
\text { delkezik / nem rendelkezik vele }\end{array}$ & $\begin{array}{c}\text { Levegővel } \\
\text { tehermentesített } \\
\text { csúszóvezeték }\end{array}$ & $\begin{array}{c}\text { Olajjal } \\
\text { tehermentesített } \\
\text { csúszóvezeték }\end{array}$ \\
\hline Merevség & $\mathrm{x}$ & $\mathrm{o}$ \\
\hline Csillapítási képesség & $\mathrm{x}$ & $\mathrm{o}$ \\
\hline Úszás jelenség & $\mathrm{x}$ & $\mathrm{o}$ \\
\hline Billenés jelenség & $\mathrm{x}$ & $\mathrm{o}$ \\
\hline Előtoló erő & $\mathrm{o}$ & $\mathrm{o}$ \\
\hline Kenőközeg keringtetése & $\mathrm{o}$ & $\mathrm{x}$ \\
\hline
\end{tabular}

Az 1. táblázat összehasonlítja a különböző közeggel tehermentesített csúszóvezeték tulajdonságait. Az összenyomhatatlan kenőközeggel a csúszóvezetékek kenése ugyanolyan jó, mint sürített levegös kivitelnél, miközben a konstrukció merevsége sokkal nagyobb. A hidrosztatikus hatás olajjal sokkal 
könnyebben biztosítható, mivel ezeknek a vezetékeknek a gyártási pontossága, föleg nagy vezetékek esetében nem kell olyan szigorúnak lennie, mintett sürített levegő alkalmazása esetén.

Az 1. ábra egy olajjal tehermentesített csúszóvezeték perspektivikus nézete látható, amelynek elötolási pontossága meghaladja a korábban ismertetett vezetéktípusokét.

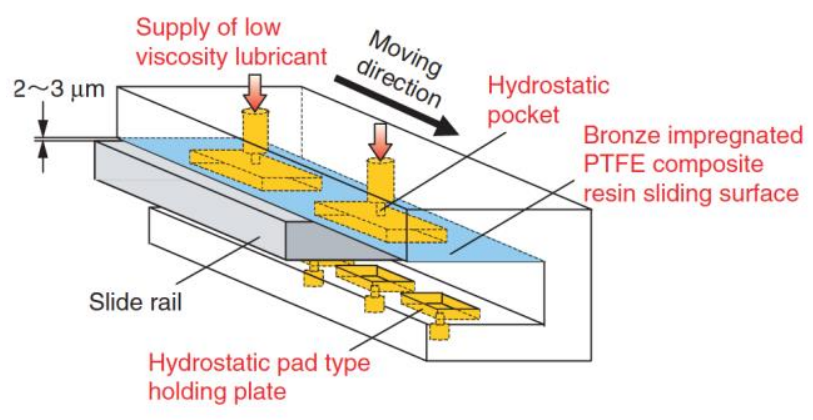

\section{1. ábra. Olajjal tehermentesitett csúszóvezeték [1].}

A terhelőerő csökkentésére alkalmazott zsebek nem egyszerü nyomózsebek, hanem nyomáscsökkentő funkcióval rendelkező hidrosztatikus papucsok. Nagy sebességü előtolás esetén ezek a hidrosztatikus zsebek szüntetik meg a hidrosztatikus hatásból származó úszás jelenségét. Így megoldható a nagy sebességü előtolásnál fellépő túlzott mértékủ elmozdulás kompenzálása, amely a legnagyobb problémát jelenti a részlegesen úszó vezetékeknél. Az olajjal tehermentesített csúszóvezeték egy hidrosztatikus zsebekkel ellátott tartólappal van ellátva az úszó mozgás további korlátozása céljából, amely a részlegesen tehermentesített csúszóvezetékek egyik hátránya. A hidrosztatikus párna egy epoxigyanta bevonattal van ellátva, hogy egy esetleges túllendülés-gátlást biztosítson.

A részlegesen tehermentesített csúszóvezetékek képesek a csúszófelületek érintkezési nyomásának megfelelő beállítására a hidrosztatikus nyomás megváltoztatásával anélkül, hogy jelentős résváltozások történnének. A csúszófelületen lévő érintkezési nyomás változtatható a zsebek olajellátásának megváltoztatásával annak érdekében, hogy csökkentsék a terhelőerőt. Az állandó előtolási ellenállást és az elötolási pontosságot a munkadarabtól függetlenül is fenntartható. Aktív terheléskorrekciós rendszer használata esetén a szabályzó egység automatikusan felismeri a munkadarab súlyát, és ennek megfelelően kiválasztja az optimális előtolási paramétereket.

Középoszlopos megmunkáló központokban, ahol a csúszófelületekre több tonna terhelés hat, nem könnyü biztosítani a pontos előtolást.

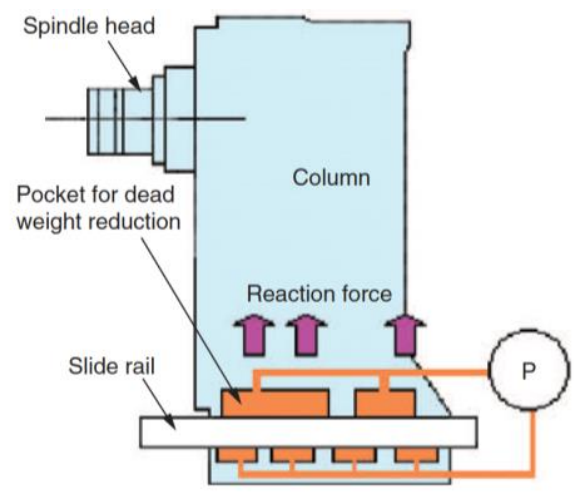

2. ábra. Egyenetlen terhelés kompenzálása középoszlopos megmunkáló gépen [1]. 
Ahhoz, hogy a Hiba! A hivatkozási forrás nem található.án bemutatott egyenetlen terhelést meg tudjuk támasztani, az erősebb súlycsökkentő zsebek úgy vannak kialakítva és elrendezve CAE rendszerben történő szerkezeti elemzés alapján, hogy a vezeték ne deformálódjon el. Az előfeszített terheléskorrekciós funkció a megbízhatóságot a vezeték csúszásából származó kopásának minimalizálásával javítja [1].

A mérések elvégzéséhez egy korábbi, gördülő papucsok vizsgálatára kifejlesztett berendezés került átalakításra. Ezzel a berendezéssel egyszerre $8 \mathrm{db}$ gördülőpapucs vizsgálatára volt lehetőség. A vizsgáló berendezés vázelemeit, papucs befogó és terhelő rendszerét meghagyva a korábban vizsgált gördülőpapucsok helyére kerültek beszerelésre (3. ábra). A nyomókamrás próbatestek segítségével meg lehet vizsgálni, hogy egy elöre beállított terhelés esetén mekkora nyomásnál csökken le a gerenda megmozdításához szükséges erő, illetve le lehet ellenőrizni az olajelvezető csatornák müködését.

A próbatestek egy központi négyszögletü gerenda köszörült oldalfelületein úgy helyezkednek el, hogy mindegyik vezető felületen 2-2 papucs található. 4-4 próbatest egy-egy alaplapra „V” alakban (negatív prizma forma) került beszerelésre. Az egyik alaplap az állványhoz van rögzítve, a másik az alsó alapra ráhelyezett gerendára kerül. Az alaplapokat közrefogják a terhelőgyürük. A próbatestek olajellátása egy közös hidraulikus vezetékröl történik, ezért mindegyik nyomókamrában ugyan akkora nyomás lesz, mindegyik próbatestnél ugyan akkora hidraulikus erő keletkezik. A résáram gyüjtő csatornák papucsonként külön-külön kivezetésre kerültek, ezért jól megfigyelhetö, ha valamelyik papucsnál megindul résáram. A páronként szemben lévő papucsokra terhelő erőt egy, a papucsok terhelési középpontjában lévő fészekben megtámasztott, acélgyürü megfeszítésével lehet létrehozni.

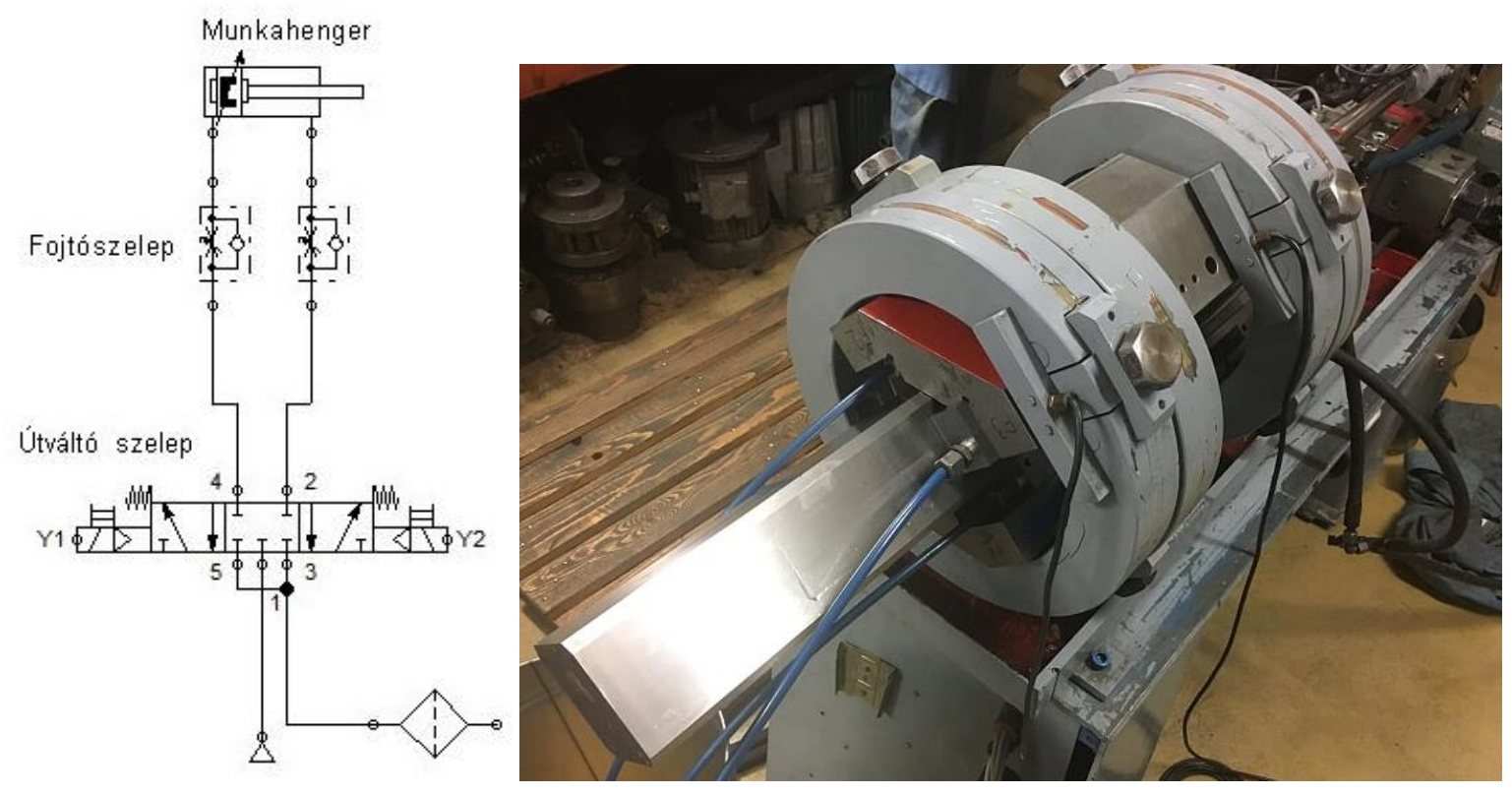

3. ábra. Vizsgáló berendezés elötoló munkahengerének kapcsolási rajza és az összeszerelt vizsgáló berendezés.

\subsection{Próba vezetékpapucsok kialakítása}

A vizsgáló berendezésen végzett próbamérések során tapasztalt korai, a felfekvő felületeknél megjelenő résolaj felhívta a figyelmet arra, hogy fokozott figyelmet kell fordítani az összetartozó vezeték felületeknél a minimális illesztési hézag kialakítására. Ezért ellenőrzésre került a gerenda felületek párhu- 
zamossága. Ez a mérés csak néhány $\mu$ m-es hibát mutatott ki. Ezután a gerenda és a felfogó szögelem szöghibájának ellenőrzése is elvégzésre került tusírfestékes módszerrel, ahol már jelentősebb alakhiba került kimutatásra.

A gerenda és a próbatest felfogó szögelemek utólagos munkálására nincs lehetőség, ezért új próbatestek kerültek legyártásra. Az új próbatesteknél a siklófelület un. felületképző eljárással készült el a mügyanta alapú Moglice vezetékanyagból. Ez a technológia biztosítja, hogy a felfogó bázisfelületek hibája ne befolyásolja a vezeték felületek illeszkedését. A próbatest öntöttvas alaptestében a Moglice réteg számára kialakított fészek a töltő ill. túlfolyó furatokkal lett ellátva. A próbatesteknél a vezető felület Moglice FL/P injektálható epoxigyanta alapú vezetékanyagból készült el formaleképző eljárással. Ennél a módszernél a vezető felület kialakítása az ellenfelület felhasználásával történik.

Az összeszerelt berendezésnél a próbatestekben kialakított, a vezeték gerenda köszörült felületével lezárt fészkek injektáló módszerrel kerültek kitöltésre Moglice vezeték anyaggal. Így a próbatesteknél kikeményedés után, a gerenda egy keresztmetszetében, vezeték felületéhez tökéletesen illeszkedő ellenfelület kapható. Illeszkedési hiba csak a gerenda párhuzamossági hibájából adódhat, de ez a mérések alapján a párhuzamossági hiba a gerendában 1-2 $\mu \mathrm{m}$ értéken belül van.

A próbatestbe kitöltésnél beszerelésre kerültek a töltő és a túlfolyó csatlakozók. A töltő csatlakozón keresztül lehet a kamrát a Moglice FL/P anyaggal feltölteni, a túlfolyó csatlakozón keresztül távozhat a levegő feltöltés közben. A nyomókamrákban lévő Moglice nyomása megemelheti a felső elemet. A megemelés elkerüléséhez terhelősúlyokat alkalmaztunk, hogy a felső rész a Moglice megkötéséig biztonsággal felfeküdjön a gerendára. A kitöltés után a nyomókamra és résolaj elvezető gyürü utólagosan lettek megmunkálva (4. ábra).

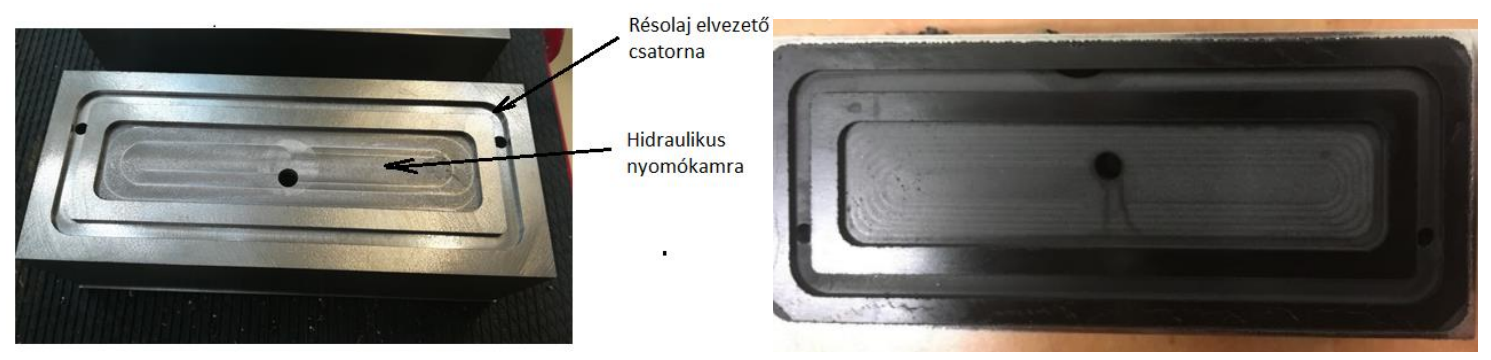

4. ábra. Az eredeti öntöttvas próbatest és a kész próbatest Moglice FL/P csúszófelülete az utólagos megmunkálással elkészitett nyomókamrával és szivárgó olaj gyüjtö csatornával.

\section{Mérési eredmények}

A vizsgálat célja az, hogy ha nyomókamrás próbatestek terhelése fokozatosan növekszik, akkor mekkora kamranyomás esetén tapasztalható jelentősebb eröcsökkenés az előtoló erőben. Az előtoló henger kamranyomásai a munkahenger hidraulikus csatlakozóiba bekötött nyomástávadókkal olvasható le.

A terhelést a próbatesteket hordozó befogó elemeket közrefogó terhelő gyürủ támasztó csavarjainak meghúzási nyomatékával kehet beállítani, amelyből a támasztó csavar magátméröjének és mentemelkedésének ismeretében visszaszámolható az előfeszítő erő nagysága.

A mérések során a terheletlen állapot és három meghúzási nyomaték alatti $(5 \mathrm{Nm}, 10 \mathrm{Nm}$ és 15 $\mathrm{Nm})$ viselkedés került megvizsgálásra. A kamranyomás növelése közben szemrevételezéssel lett ellenőrive, hogy a nyomókamrák kivezető csövein olajszivárgás tapasztalható-e, és ha igen, akkor milyen mértékben. A nyomás növelésének hatására a terhelő gyürük rugalmas deformációt szenved- 
nek, ami a vezetékhézag megnövekedését, és ez által a résolaj megindulását eredményezik. Ez a résolaj jelenik meg olaj elvezető csöveken a nyomás növelése közben.

2. táblázat. Terheletlen állapotban mért kamra és munkahenger nyomások.

\begin{tabular}{|c|c|c|c|c|c|c|}
\hline \multirow{3}{*}{$\begin{array}{c}\text { Kamranyomás } \\
\text { [bar] }\end{array}$} & \multicolumn{4}{|c|}{$\begin{array}{c}\text { Munkahenger nyomás } \\
\text { [bar] }\end{array}$} & \multirow{3}{*}{ Kamraszivárgás } & \multirow{3}{*}{ Megállapítás } \\
\hline & \multicolumn{2}{|c|}{ + irány } & \multicolumn{2}{|c|}{ - irány } & & \\
\hline & $\mathrm{p} 1$ & $\mathrm{p} 2$ & $\mathrm{p} 1$ & p2 & & \\
\hline 0 & 6,2 & 3,2 & 3,3 & 12,7 & szivárgás nincs & $\begin{array}{c}\text { szlippelve mozog + } \\
\text { irányba } \\
\text { egyenletesen mozog - } \\
\text { irányba }\end{array}$ \\
\hline 5 & 2,7 & 3,5 & 4,5 & 8 & folyik & egyenletesen mozog \\
\hline
\end{tabular}

3. táblázat. 5 Nm-es meghúzási nyomatéknál (1,6 kN elöfesz.) mért kamra és munkahenger nyomások.

\begin{tabular}{|c|c|c|c|c|c|c|}
\hline \multirow{3}{*}{$\begin{array}{c}\text { Kamranyomás } \\
\text { [bar] }\end{array}$} & \multicolumn{4}{|c|}{$\begin{array}{c}\text { Munkahenger nyomás } \\
\text { [bar] }\end{array}$} & \multirow{3}{*}{ Kamraszivárgás } & \multirow{3}{*}{ Megállapítás } \\
\hline & \multicolumn{2}{|c|}{ + irány } & \multicolumn{2}{|c|}{ - irány } & & \\
\hline & p1 & p2 & $\mathrm{p} 1$ & p2 & & \\
\hline 0 & 12,7 & 2,7 & 3,2 & 12,2 & nincs & $\begin{array}{l}\text { indulási nyomás: } 20 \\
\text { bar }\end{array}$ \\
\hline \multirow[b]{2}{*}{5} & 12,7 & 2,7 & 3,2 & 12,2 & $\begin{array}{l}\text { gyengén néhány } \\
\text { csövön csepegni } \\
\text { kezd }\end{array}$ & áll, majd megindul \\
\hline & 10,5 & 3 & 4,2 & 10,8 & csepeg & $\begin{array}{c}\text { + irányba erősen } \\
\text { szlippel } \\
\text { - irányba gyengébben } \\
\text { szlippel }\end{array}$ \\
\hline 10 & 4,2 & 7,5 & 2,7 & 2,7 & folyik & egyenletesen mozog \\
\hline
\end{tabular}


4. táblázat. 10 Nm-es meghúzási nyomatéknál (3,3 kN) mért kamra és munkahenger nyomások.

\begin{tabular}{|c|c|c|c|c|c|c|}
\hline \multirow{3}{*}{$\begin{array}{l}\text { Kamranyomás } \\
\text { [bar] }\end{array}$} & \multicolumn{4}{|c|}{$\begin{array}{c}\text { Munkahenger nyomás } \\
\text { [bar] }\end{array}$} & \multirow{3}{*}{ Kamraszivárgás } & \multirow{3}{*}{ Megállapítás } \\
\hline & \multicolumn{2}{|c|}{ + irány } & \multicolumn{2}{|c|}{ - irány } & & \\
\hline & p1 & p2 & p1 & p2 & & \\
\hline 0 & 20,7 & 2,3 & 2,8 & 20,7 & nincs & áll \\
\hline 5 & 20,7 & 2,3 & 2,8 & 20,7 & nincs & áll \\
\hline 10 & 20,7 & 2,3 & 2,8 & 20,7 & $\begin{array}{l}\text { csepegés megjelent } 3 \text { alsó } \\
\text { és egy felsö csövön }\end{array}$ & $\begin{array}{l}\text { áll majd szlippelve meg- } \\
\text { mozdul }\end{array}$ \\
\hline 15 & 3 & 2,5 & 3,8 & 6,5 & $\begin{array}{l}2 \text { csövön vékonyan fo- } \\
\text { lyik, a többi csepeg }\end{array}$ & egyenletesen mozog \\
\hline
\end{tabular}

5. táblázat. 15 Nm-es meghúzási nyomatéknál (4,9 kN.) mért kamra és munkahenger nyomások.

\begin{tabular}{|c|c|c|c|c|c|c|}
\hline \multirow{3}{*}{$\begin{array}{c}\text { Kamranyomás } \\
\text { [bar] }\end{array}$} & \multicolumn{4}{|c|}{$\begin{array}{c}\text { Munkahenger nyomás } \\
\text { [bar] }\end{array}$} & \multirow{3}{*}{ Kamraszivárgás } & \multirow{3}{*}{ Megállapítás } \\
\hline & \multicolumn{2}{|c|}{ + irány } & \multicolumn{2}{|c|}{ - irány } & & \\
\hline & p1 & $\mathrm{p} 2$ & p1 & $\mathrm{p} 2$ & & \\
\hline 0 & 20,2 & 2 & 2,5 & 19,7 & nincs & áll \\
\hline 5 & 20,2 & 2 & 2,5 & 19,7 & nincs & áll \\
\hline 10 & 20,2 & 2 & 2,5 & 19,7 & nincs & áll \\
\hline 15 & 20,2 & 2 & 2,5 & 19,7 & nincs & áll \\
\hline 20 & 2,5 & 3,5 & 3,5 & 6,5 & $\begin{array}{l}\text { indítás elött néhány veze- } \\
\text { ték csöpög, indulás után a } \\
\text { csöpögés intenzívebb } \\
\text { lesz, a munkahenger } \\
\text { felöli oldalon néhány } \\
\text { vezetéknél folyás is meg- } \\
\text { jelenik }\end{array}$ & $\begin{array}{l}\text { szlippelve megindul, majd } \\
\text { egyenletesen mozog }\end{array}$ \\
\hline 25 & 2,2 & 2,2 & 3,5 & 6 & $\begin{array}{l}\text { intenzív folyás a munka- } \\
\text { henger felöli oldalon, a } \\
\text { másik oldalon egy veze- } \\
\text { ték folyik, a többi csöpög }\end{array}$ & egyenletesen mozog \\
\hline
\end{tabular}

A 0 és 5 bar-os kamranyomások esetén indulási nyomás nem került mérésre, mert mind a munkahenger, mind a vezeték egység felfogó eleme a 20 bar-os nyomás estén is jelentős mértékben deformálódott. Fennállt a veszélye, hogy nagyobb erők esetén maradandón károsodik a berendezés. Papucstest 
csúszó felület tömítettségének ellenőrzése során megfigyelésre került, hogy amíg a szivárgó vezetéken maximum csöpögés volt látható, addig a papucs oldalfelületén csorgás nem tapasztalható, de mikor a szivárgó vezetéken olajfolyás van, akkor az oldalfelületen is megjelenik az olajszivárgás.

\section{4. Összefoglalás}

Részlegesen tehermentesített, kombinált vezetékkonstrukciók kerültek megvizsgálásra, amelynek segítségével egy hidraulikus nyomókamrákkal tehermentesített csúszóvezeték konstrukció került kialakításra. A tehermentesítés nagyságának ellenőrzéséhez egy mérőpad lett felállításra. A mérések alapján látható, hogy hidraulikus nyomókamrákkal létrehozható az ellenerő, amely alkalmas a súrlódó vezeték tehermentesítésére. Nagyon érzékeny a rendszer a vezető felületek alakhibáira, néhány $\mu \mathrm{m}$-es eltérés már a résolaj megjelenését eredményezi. Ha a gép rugalmas deformációja néhány $\mu \mathrm{m}$-es párhuzamossági hibát okoz, az a résolaj korai megjelenését eredményezi. A résolaj mennyisége a nyomás növekedésével nő. Ez részben abból adódik, hogy a nagyobb nyomás a meglévő résen nagyobb térfogatáramot hajt keresztül, másrészt a nagyobb nyomásból adódó nagyobb terhelö erő a terhelö gyürüket jobban deformálja, amely résméret növekedést eredményez. A szán megindításához lényegesen nagyobb erö szükséges, mint mozgásban tartásához.

\section{Köszönetnyilvánítás}

A cikkben ismertetett kutató munka az EFOP-3.6.1-16-2016-00011 jelü „Fiatalodó és Megújuló Egyetem - Innovatív Tudásváros - a Miskolci Egyetem intelligens szakosodást szolgáló intézményi fejlesztése" projekt részeként - a Széchenyi 2020 keretében - az Európai Unió támogatásával, az Európai Szociális Alap társfinanszírozásával valósul meg.

\section{Irodalom}

[1] Saito, T.: Development of Machine Tool's Guideways-Dynamically pressurized, Statically Pressurized and Partially Floated Guideways, JTEKT Engineering Journal No. 1001E (2006) pp. 57-64.

[2] Mehta, N.K.: Machine tool Design and Numerical Control 2nd. edition, McGraw-Hill Publishing Comapany, Új Delhi 1996., ISBN 0074622374, pp. 220-221.

[3] Rowe, W.B.: Hydrostatic, Aerostatic, and Hybrid Bearing Design, Elsevier, 2014., ISBN 978012396994-1

[4] Bassani, R., Piccigallo, B.: Hydrostatic Lubrication, Tribology Series 22, Elsevier,1992., ISBN 044488498 